\title{
Hypertension: Pathophysiology and Treatment
}

Sinny Delacroix ${ }^{1}$, Ramesh G Chokka ${ }^{1,2}$ and Stephen G Worthley ${ }^{2 *}$

${ }^{1}$ Cardiovascular Research Centre, Royal Adelaide Hospital and Department of Medicine, University of Adelaide, Adelaide, SA, Australia

${ }^{2}$ South Australian Health and Medical Research Institute, North Terrace, Adelaide, SA, Australia

"Corresponding author: Stephen G Worthley, Helpman Chair, Cardiovascular Medicine, University of Adelaide, Adelaide, SA 5000, Tel: +61 (8)82225608; Fax: +61 (8)82222454; E-mail: stephen.worthley@adelaide.edu.au

Received date: Aug 04, 2014, Accepted date: Nov 20, 2014, Published date: Nov 25, 2014

Copyright: ( 2014 Delacroix S, et al. This is an open-access article distributed under the terms of the Creative Commons Attribution License, which permits unrestricted use, distribution, and reproduction in any medium, provided the original author and source are credited.

\begin{abstract}
Hypertension is a significant risk factor for heart disease, stroke and other cardiovascular diseases and an estimated 970 million people worldwide suffer from the disease resulting in significant morbidity, mortality and financial burden globally. Despite significant advances in pharmaceutical treatment only $53 \%$ achieve targeted blood pressure goals largely due to poor patient compliance compelling a structured and flexible yet, individually tailored approach for treatment of HTN.1, 2This review addresses the pathophysiology, diagnosis and current management for the disease.
\end{abstract}

Keywords: Hypertension; Sympathetic nervous system; Reninangiotensin-aldosterone system; Renal denervation

\section{Introduction}

Hypertension (HTN), defined as systolic blood pressure (SBP) > $140 \mathrm{mmHg}$ or diastolic blood pressure (DBP) $>90 \mathrm{mmHg}$, is a major growing health problem across the globe [1-5]. It is the most common risk factor for cardiovascular disease and affects nearly two-thirds of adults aged 60 years or older [1,2]. It is estimated that uncontrolled HTN is responsible for 7.5 million deaths per year worldwide [6] and in USA alone accounts for over 47 billion dollars spent in health care services, medications and absent workforce [7]. Despite various advances in the field it is projected that 1.56 billion people will suffer from HTN by 2025.3 Various randomized controlled trials have demonstrated that even slight blood pressure decreases such as $10 \mathrm{mmHg}$ reduces patients risk of death due to cardiovascular disease by $25 \%$ and, similarly decreases risk of stroke related mortality by $40 \%$, [8] demonstrating the pressing need for novel therapies in the treatment of this pathology.

Our initial understanding of central aortic pressure and therefore "blood pressure" dates back to 1733 when Stephen Hales directly measured intra-arterial pressure in a horse [9]. Subsequently, it took almost a century to develop sphygmomanometric devices that could potentially measure blood pressure noninvasively and these devices were introduced into clinical practice in the late 1800s and early 1900s [10]. Although the variability of blood pressure in response to various physical/emotional stimuli and sleep/wake periods gained attention even in the 1940's [11] it's significance became more evident towards the end of the 20th century when mercury manometers were replaced with electronic devices making blood pressure measurements safe and accessible. As early as 1906, insurance companies in the United States were the first to conduct initial studies identifying the risks associated with high blood pressure [12] and in the 1920's several studies not only concurred with their findings but further identified that HTN is often associated with comorbidities such as insulin resistance [13] and central obesity [14].
Figure 1: Systems involved in the development and maintenance of hypertension

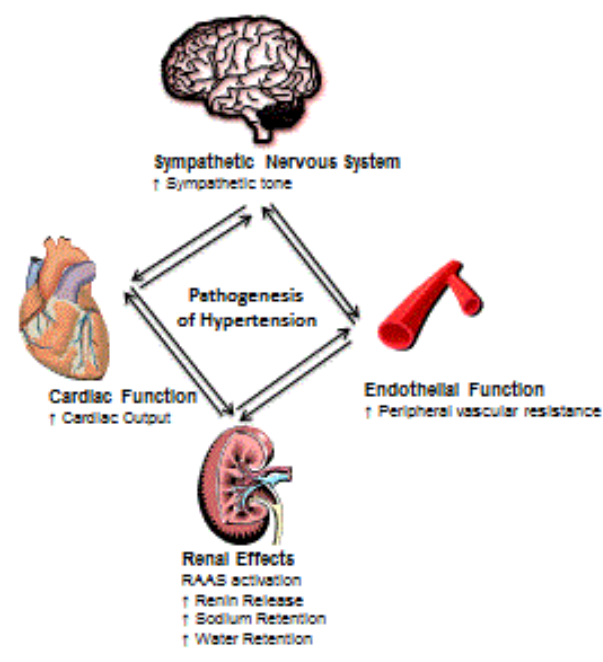

Figure 1: Systems involved in the development and maintenance of hypertension

\section{Pathophysiology}

HTN can be classified as primary (or essential) HTN and secondary HTN accounting for $95 \%$ and $5 \%$ of hypertensive patients respectively [15]. Although the aetiology of essential HTN is unknown, it typically begins in the fifth or sixth decade of life, is often associated with increased salt intake and obesity and has a strong relationship with family history, underscoring the possibility of genetic predisposition for the disease [16]. Conversely identifiable causes such as renal artery stenosis, chronic kidney disease, sleep apnoea and adrenal diseases accompany secondary HTN [15]. The common phenomenon in both 
scenarios is the derangement of multiple mechanisms involved in the maintenance of normal blood pressures and as such, the sympathetic nervous system, renin-angiotensin-aldosterone system, endothelial function plus sodium and water retention have been extensively studied to ascertain mechanisms involved in the development of the disease[17,18] Figure 1.

\section{Cardiac output and peripheral vascular resistance (PVR):}

Cardiac output and PVR are two important factors that maintain normal blood pressures and it has been suggested that increased cardiac output resulting from sympathetic dysfunction is the trigger for the development of HTN and increases in PVR is essentially the physiologic response to accommodate change in pressure and maintain homeostasis [17-19].

\section{Sympathetic nervous system:}

Over the last decade the role of SNS in the development and maintenance of blood pressure has been studied exhaustively and it has been identified that sympathetic stimulation of the heart, peripheral vasculature, and kidneys, resulting in increased cardiac output, increased vascular resistance, plus fluid retention is important in the development and maintenance of this disease [20]. As evidenced in the Coronary Artery Risk Development in Young Adults (CARDIA) study, sympathetic overdrive is often accompanied by low parasympathetic tone, which further exacerbates the condition [21]. Additionally, several studies have demonstrated evidence of sympathetic over activity by documenting increases in norepinephrine spill over in patients with HTN confirming that sympathetic over activity is a core component in the pathophysiology of this disease. The renal sympathetic nervous system is a major player in the development and maintenance of HTN affecting blood pressure via two pathways, namely, the efferent and afferent pathways. The efferent pathway carries signals from the SNS to the kidney and increases renin release thereby activating the RAAS system and increasing sodium and water retention, all resulting in increased circulating volumes and therefore increased blood pressures. In addition to the aforementioned processes the efferent pathway also decreases renal blood flow and to increase perfusion the kidney triggers the afferent pathway that carries impulses to the SNS exacerbating sympathetic over activity and thereby maintaining the high blood pressures.

\section{Renin-angiotensin-aldosterone system (RAAS):}

The RAAS system plays a major role in orchestrating the maintenance of normal blood pressures and is activated by dual mechanisms, stimulation of the SNS and glomerular under perfusion [22-24]. These stimuli trigger the release of renin from the juxtaglomerular apparatus which converts angiotensinogen to inactive angiotensin $\mathrm{I}$, the latter is further cleaved by endothelium bound angiotensin converting enzyme (ACE) into angiotensin II, the active component of this cascade and a potent vasoconstrictor [22-27]. Although this conversion of angiotensin I to angiotensin II was initially believed to occur primarily in the lungs, it has since been established that the process occurs practically in all tissues. In response to decreased salt intake RAAS also triggers the release of aldosterone from the adrenal glands that increases salt reabsorption coupled with water retention resulting in further increase of blood pressure [22-28]. Under these circumstances one would expect that patients with HTN would invariably have high circulating levels of renin and angiotensin II, however, studies have demonstrated that plasma renin activity is increased in 15 percent patients, normal in 60 percent patients, and reduced in approximately 25 percent patients [29]. This can be reconciled by growing evidence for the presence of local renin systems regulating regional blood flow that might play an essential part in the pathophysiology of HTN [30-32].

\section{Endothelial dysfunction:}

Whether endothelial dysfunction is a cause or an effect of hypertension is debatable, nonetheless there is substantial evidence linking endothelial dysfunction with hypertension [33-36]. In fact, there is evidence of a positive association between the degree of endothelial dysfunction and the severity of hypertension [37]. The major underlying mechanism for endothelial dysfunction seen in HTN is the decrease in the availability of nitric oxide (NO), a consequence of increased oxidative stress in these patients. To this, extent although effective antihypertensive therapy restores impaired nitric oxide production, endothelium dependent vasorelaxation continues to be altered suggesting an irreversible course once HTN is established. This evidence as well as studies demonstrating that inhibition of endothelium-derived nitric oxide synthase (eNOS) results in hypertension in humans, insinuates endothelial dysfunction as a potential aetiological factor in the initiation of HTN [38]. On the other hand the Multiethnic Study of Atherosclerosis (MESA) showed that impaired flow-mediated dilation (FMD) was not a significant independent predictor of the future development of hypertension [39] and Juonala et al (2006) demonstrated an association of higher blood pressures in adolescence with endothelial dysfunction in adulthood [40]. In addition to NO other vasorelaxing factors such as arachidonic acid metabolites, reactive oxygen species (ROS), vasoactive peptides and microparticles of endothelial origin play important roles in maintenance of vascular tone. Emerging data suggests that these factors contribute to excessive vascular oxidative stress and vascular inflammation resulting in endothelial dysfunction [41,42]. In the recent years endothelial progenitor cells (EPC's) that develop to form mature endothelial cells has been implicated in the maintenance of arterial stiffness and as such are now considered as determinants of endothelial function [43,44]. Thus endothelial dysfunction is multifactorial and a myriad of alterations in the vascular milieu lead to structural and functional changes within the arteries and therapies targeting key pathways involved in the process have shown to decrease vascular remodeling, improve vascular function and therefore attenuate overall cardiovascular risk.

Whilst due to its relevance endothelial function was initially measured in the coronary arteries invasively using acetylcholine or other pharmacologic flow manipulation, current methodologies include venous plethysmography, digital pulse tonometery, laser Doppler flowmetry and the most common high-resolution ultrasound [45]. These methods have not only made early identification of endothelial dysfunction possible and but has also broadened the horizon of FMD in determining efficacy of treatment and assessing prognosis in patients with HTN and other cardiovascular diseases.

\section{Vasoactive substances:}

Endothelin, a potent vasoconstrictor is one of the major substances involved in maintaining vascular tone. Identified by Hickey et al in 1985, it is secreted by endothelial cells and exerts its affects in a paracrine or autocrine manner on vascular smooth muscle cells and counteracts the relaxing activity of NO [46,47]. Studies have demonstrated that both in animals and humans infusion of 
endothelin-1 (ET-1) results in increased blood pressures [48] and blocking the system using antagonists reverts the phenomenon [49]. However, plasma levels of ET-1 are normal in patients with essential hypertension [50] suggesting that activity of this system might not play a role in all types of HTN but rather in specific disease states such as salt-sensitive HTN and renal HTN. Large clinical trials aimed at determining both the importance of endothelin in the development and maintenance of HTN and, ascertaining necessity of treatments targeted towards maintenance of this system are warranted.

Bradykinin a vasodilatory peptide with autocrine and paracrine function has long had an indirect association with HTN since apart from its direct vasodilatory affects, bradykinin stimulates release of other vasoactive substances like prostaglandins. This peptide from the kinin-kallikrein system is shown to reduce blood pressures by vasodilation as well as enhanced natriuresis and diuresis both achieved via increased renal blood flow mediated by $\mathrm{NO}$ and prostaglandin release [51-53]. Although vastly overlooked due to side effects of coughing and angioedema the hypotensive effects of ACE inhibitors is due to increased bradykinin levels owing to its reduced degradation $[54,55]$ therefore therapies targeted directly at bradykinin system are likely in the not so distant future.

Atrial natriuretic peptide (ANP) belongs to a family of structurally and functionally related peptide hormones with cardio-renal functions. ANP mediates its functions via membrane-bound guanylatecyclase linked receptor (NPR-A), which further activates intracellular cGMP mediated processes. Released from the atria in response to atrial distention stemming from hemodynamic overload, ANP causes natriuresis and diuresis resulting in modest reductions in blood pressures with concomitant decreases in plasma renin and aldosterone. Thus, the natriuretic peptide system by decreasing peripheral vascular resistance balances the activity of the SNS and the RAAS system in maintaining blood pressures [56,57].

\section{Diagnosis and patient evaluation}

Measurement of blood pressures can be done either manually using a sphygmomanometer or an automated electronic device (both office and home) or when feasible ambulatory blood pressure monitoring is utilized. The latter two are preferred since they are reproducible and rule out observer bias. Readings are measured in both arms using arm cuffs for accuracy. The use of finger cuffs is strongly discouraged due to lack of reproducibility. Blood pressure measurements are taken on an empty bladder with the patient well positioned, legs resting on the ground and arms resting comfortably on a table. An average of two readings taken approximately 5 minutes apart is taken at two visits to determine blood pressure. In older patients postural hypertension is also assessed. In addition to blood work and electrocardiography, it is important to consider all previous cardiovascular events, risk factors plus other medical and medication history (stroke, transient ischemic attacks, coronary artery disease, heart failure, chronic kidney disease, peripheral artery disease, diabetes and sleep apnea) to determine an appropriate treatment plan.

\section{Treatments of hypertension}

\section{Overall goals of treating HTN:}

Although reducing blood pressure is pivotal in treating patients with HTN, it is equally important to efficiently manage other cardiovascular risk factors such as lipid disorders, diabetes/glucose intolerance, obesity and smoking. The classification for hypertension as per the ASH and ESH/ESC guidelines is given in Table 1. The treatment goal in hypertensive patients is a reduction of SBP to $<140 \mathrm{mmHg}$ and DBP to $<90 \mathrm{mmHg}$. Previously in patients with diabetes, chronic kidney disease and coronary artery disease the targeted blood pressures were $<130 / 80 \mathrm{mmHg}$, however, due to lack of corroborating evidence of improvements with these parameters blood pressures of $<140 / 90 \mathrm{mmHg}$ is widely used except in chronic kidney disease patients with albuminuria, where experts still recommend blood pressures $<130 / 80 \mathrm{mmHg}[4,5,58-61]$. Another exception to the rule is patients aged 80 years or older where blood pressures $<150 / 90$ $\mathrm{mmHg}$ is acceptable since recent studies have demonstrated that achieving SBP $<150 \mathrm{mmHg}$ in the this group decreased cardiovascular events and stroke $[4,16,62]$. ASH and ESH/ESC current guidelines for treatment goals in various categories and disease states are given in Table 2.

\begin{tabular}{|c|c|}
\hline Category & ASH* $^{*} 2013$ \\
\hline General > 60 y & $<150 / 90$ \\
\hline General < 60y & $<140 / 90$ \\
\hline Diabetes & $<140 / 90$ \\
\hline CKD & $<140 / 90$ \\
\hline Category & ESH/ESC ${ }^{* *} 2013$ \\
\hline General nonelderly & $<140 / 90$ \\
\hline General elderly $<80 y$ & $<150 / 90$ \\
\hline General > 80 y & $<150 / 90$ \\
\hline Diabetes & $<140 / 85$ \\
\hline CKD no proteinuria & $<140 / 90$ \\
\hline CKD with proteinuria & $<130 / 90$ \\
\hline
\end{tabular}

Table1: Classification of office blood pressures (mmHg) as per ASH and ESH/ESC guidelines;ASH: American Society of Hypertension; ${ }^{* *}$ ESH/ESC: European Society of Hypertension/European Society of Cardiology\#SBP: Systolic Blood Pressure, \#\#DBP: Diastolic Blood Pressure

\begin{tabular}{|l|l|l|}
\hline Category & \multicolumn{2}{|l|}{ ASH $^{*}$ 2013 } \\
\hline & SBP\# & DBP\#\# \\
\hline Normal & $<120$ & $<80$ \\
\hline Prehypertension & $120-139$ & $80-89$ \\
\hline Stage 1 Hypertension & $140-159$ & $90-99$ \\
\hline Stage 2 Hypertension & $>160$ & $>100$ \\
\hline Category & ESH/ESC $^{\text {** } 2013}$ \\
\hline & SBP\# & DBP\#\# \\
\hline Normal & $120-129$ & $80-84$ \\
\hline High Normal & $130-139$ & $85-89$ \\
\hline Grade 1 Hypertension & $140-159$ & $90-99$ \\
\hline
\end{tabular}




\begin{tabular}{|l|l|l|}
\hline Grade 2 Hypertension & $160-179$ & $100-109$ \\
\hline Grade 3 Hypertension & $>180$ & $>110$ \\
\hline
\end{tabular}

Table 2: Treatment goals of hypertension; ${ }^{\star}$ ASH: American Society of Hypertension $^{\star \star}$ ESH/ESC: European Society of Hypertension/ European Society of Cardiology\#CKD: Chronic Kidney disease

\section{Non-pharmacologic treatment of HTN:}

The importance of lifestyle changes like weight reduction, dietary salt reduction, regular aerobic exercise, smoking cessation and reduction in alcohol consumption cannot be stressed enough and has to be complemented along with drug therapy in all patients with HTN. The benefits of these changes are apparent in various studies revealing reductions in systolic blood pressures Table 3. In fact, in prehypertensive patients with SBP between 120-139 mmHg and DBP between $80-89 \mathrm{mmHg}$ merely making lifestyle changes would delay and possibly halt progression to HTN. Similarly, even in patients with stage I HTN (SBP between 140 to $159 \mathrm{mmHg}$ and DBP between 90-99 $\mathrm{mmHg}$ ) life style changes for 6-12 months might preclude the necessity for drug therapies and should be encouraged in the absence of cardiovascular and renal risk factors [63].

\begin{tabular}{|l|l|}
\hline Modification & Approximate SBP\# reduction \\
\hline $\begin{array}{l}\text { Weight: maintenance of normal body weight as defined by BMI of } 18.5-24.9 \\
\mathrm{~kg} / \mathrm{m} 2\end{array}$ & $5-20 \mathrm{mmHg} / 10 \mathrm{~kg}$ reduction in weight[90,91] \\
\hline $\begin{array}{l}\text { Sodium consumption: reduction of dietary sodium to less than } 100 \mathrm{mmol} \text { per day } \\
\text { (2.4 } \mathrm{g} \text { sodium or } 6 \mathrm{~g} \text { sodium chloride). }\end{array}$ & $2-8 \mathrm{mmHg}[92,93]$ \\
\hline $\begin{array}{l}\text { Physical activity: maintenance of healthy physical activity by including regular } \\
\text { aerobic activity at least } 30 \mathrm{mins} / \text { day most days of the week }\end{array}$ & $4-9 \mathrm{mmHg}[94,95]$ \\
\hline $\begin{array}{l}\text { Healthy diet: consumption of recommended servings of fruits and vegetables } \\
\text { along with reduced saturated and total fat content in diet }\end{array}$ & $8-14 \mathrm{mmHg}[92,93]$ \\
\hline $\begin{array}{l}\text { Alcohol consumption: reduction of alcohol intake to less than } 2 \text { drinks in men and } \\
\text { less than } 1 \text { drink in women }\end{array}$ & $2-4 \mathrm{mmHg}[96]$ \\
\hline Smoking: Abstinence from smoking for a one week period in habitual smoker & $3-5 \mathrm{mmHg}[97]$ \\
\hline
\end{tabular}

Table 3: Effects of life style modifications in management of hypertension

\section{Pharmacological treatments for HTN:}

Choices of drugs for HTN are influenced by age, comorbidities, ethnicity, pregnancy and other parameters necessitating individual specific treatment regimens therefore only major drug classes are discussed in this review.

ACE inhibitors have a dual mode of action. They prevent the formation of angiotensin II, the active vasoconstrictor of RAAS and they decrease the metabolism of the vasodilator bradykinin increasing its availability. These drugs are mostly well tolerated except for the occasional cases of non-dose dependent side effects of cough and angioedema seen sporadically in patients of Asian and African descent. Although these drugs can be used as monotherapy or in combination with calcium channel blockers (CCB) and diuretics the former is more beneficial in Caucasians possibly since the RAAS is less pronounced in the black population. Several studies have identified the benefits of these drugs in clinical outcomes in patients with heart failure, chronic kidney disease, left ventricular systolic dysfunction and post myocardial infarction [64-69].

Angiotensin receptor blockers (ARB's), similar to ACE inhibitors target the RAAS by blocking AT1 receptor responsible for downstream effects of angiotensin II. Owing to similar mechanisms of action, patients on these drugs share the same benefits as with ACE inhibitors mentioned earlier and as an added advantage these drugs do not cause the undesired cough [70]. Potentially ACE inhibitors and ARB can be used together for more complete blockade of the RAAS if BP control is not achieved, although often other classes of agents will be considered for combination use first (i.e. thiazide diuretics).
Calcium channel blockers (CCB's) work by binding to the L channels of vascular smooth muscle cells and disrupting influx of calcium into muscle cell preventing contraction of smooth muscle cells and cardiac myocytes. Dihydropyridine CCB's decrease blood pressures mainly via direct vasodilation and decreasing systemic vascular resistance but nondihydropyridines function by decreasing both heart rate and force of myocardial contraction. There is significant evidence demonstrating that CCB's improve all-cause mortality plus reduce risk of stroke in patients with HTN [71]. Caution should be exercised when administering these drugs in combination with $\beta$-blockers and in patients with heart failure since non-dihydropyridines are not the treatment of choice in these groups. Overall CCB's in conjunction with ACE inhibitors or ARB's are important tools in achieving significant drops in blood pressures in patients with HTN.

Diuretics function by increasing renal sodium and water excretion. It has been well documented that diuretics improve cardiovascular outcomes and reduce risk of stroke $[64,65,72,73]$. Heart failure is a long term complication of HTN and studies have demonstrated that use of spironolactone decreases risk of morbidity and mortality in hypertensive patients with heart failure [74]. Albeit thiazide diuretics are favored in clinical practice, use of loop diuretics in association with potassium sparing diuretics reduces the risk of hypokalemia and hypomagnesaemia both conditions known to thwart diuretic therapy. Finally, even small doses diuretics potentiate blood pressure lowering capacity of most antihypertensive drug regimes. However, studies have shown an increased risk of type II diabetes mellitus in patients taking thiazide diuretics. They aren't contraindicated in patients with preexisting type II diabetes mellitus, but in at risk patients, greater 
attention to lifestyle changes to reduce this risk should be considered [75-77].

Beta-blockers are the drug of choice when treating hypertensive patients with a history of myocardial infarction and heart failure. These drugs reduce cardiac output and decrease renal renin secretion, thus initial worsening of heart failure should be anticipated when commencing therapy in the presence of heart failure. Beta-blockers are known to alter glucose metabolism and mask hypoglycemia necessitating caution when used in patients at risk for diabetes. Patient compliance is a challenge with beta-blocker therapy due to its association with depression, fatigue and sexual dysfunction therefore patient education is warranted.

Aldosterone Antagonists and in particular spironolactone (belonging to the mineralocorticoid receptor antagonist family) deserves special mention due to its utility when used in combination with ACE inhibitors, ARB's, CCB's, and diuretics especially in patients with heart failure. However, it's use as an anti-hypertensive has been shown to be excellent in those patients that can tolerate it's use $[74,78,79]$. Common problems with it's use include gynaecomastia, and electrolyte disturbances such as hyperkalaemia and deteriorating renal function. The later two are more common in patients in whom renal function is already compromised, and in patients already on ACE inhibitors or ARBs [80-84].

Alpha-blocker use in treatment of HTN continues to evolve since its inception over a decade ago. This drug that inhibits vascular sympathetic tone by blocking postganglionic a1-receptors is usually used as add-on medication in patients with uncontrolled HTN or in those who have poor tolerance to other first line medications. Owing to its two main side effects, namely first dose-syncope and vasovagal syncope, a measure of caution should be practiced during initiation of such therapy. Coupling of alpha-blockers with a diuretic can increase efficiency of therapy particularly since it could potentially offset adverse glucose and lipid imbalances caused by diuretic therapy. The drug is especially useful when treating HTN in older male patients with benign prostrate hypertrophy.

Other drugs in the armamentarium against HTN include direct vasodilators and centrally acting adrenergic inhibitors however, their use in practice has diminished since their side effects outweigh benefits and are now utilised as add-on therapy in specific patient groups. Direct renin inhibitors, which target a different part of RAAS compared to ACE inhibitors and ARB's, is another option as add-on or monotherapy in patients intolerant to first line antihypertensive therapies [85]. However, further studies assessing the utility of the latter group is imperative considering the ambiguity of treatment efficacy and the potential side effects in specific patient subgroups [86-89]. Other potential targets such as endothelin receptor antagonists and vasopeptidase inhibitors have been studied but no role has yet been identified for these therapies [90].

\section{Resistant hypertension (rHTN) and treatment options}

Resistant hypertension is defined as blood pressure that remains above $140 / 90 \mathrm{mmHg}$ despite treatment with at least three antihypertensive drugs including a diuretic at optimal doses and, an estimated $10-20 \%$ of general hypertensive population suffers from this disorder [91]. Based on a US study cardiovascular risks in patients with rHTN is increased by $50 \%$ when compared to patients with controlled HTN [92]. Since sympathetic over activity underlies the pathophysiology of HTN and subsequently rHTN, surgical renal sympathetic denervation had been shown to be a treatment options many years ago in these patients [93]. The emergence of more recent catheter based techniques for this purpose have shown exciting promise with the Symplicity and EnligHTN trials (among others) using variations in renal denervation catheters. These studies confirmed the safety of the procedure and showed significant decreases in blood pressures post procedure [94-98]. The recent Symplicity HTN III trial however, failed to show any significant difference in BP between the renal denervation and sham control groups at 6 months, and has raised concerns about the genuine efficacy of this treatment. However, there seem reasonable issues with the adequacy of the denervation procedure with the first generation catheter technology, and so future randomized control trials with next generation multi-electrode systems are awaited.

\section{Conclusion}

Alterations in the sympathetic nervous system and the reninangiotensin-aldosterone system are key factors in the development and maintenance of hypertension. Changes in vascular tone and renal sodium excretion are a direct effect of this imbalance and these changes are often accompanied by alterations in baroreflexes and autoregulation, both set in place for homeostasis of blood pressure. Therefore all treatment strategies for hypertension are directed at restoring the activity of the SNS and RAAS. Although pharmaceutical therapy of HTN is quintessential, life style interventions are equally important in conquering this preventable and easily diagnosed pathology.

\section{References}

1. Go AS (2013) Heart Disease and Stroke Statistics-2013 Update: A Report From the American Heart Association. Circulation 127: E841-E841.

2. Go AS, Mozaffarian D, Roger VL, Benjamin EJ, Berry JD, et al. (2013) Heart Disease and Stroke Statistics-2013 Update A Report From the American Heart Association. Circulation 127: E6-E245.

3. Hypertension (2014). World Heart Foundation.

4. Weber MA, Schiffrin EL, White WB, Mann S, Lindholm LH, et al. (2014) Clinical practice guidelines for the management of hypertension in the community: a statement by the American Society of Hypertension and the International Society of Hypertension. J ClinHypertens (Greenwich) 16: 14-26.

5. Mancia G, Fagard R, Narkiewicz K, Redon J, Zanchetti A, et al. (2013) Hypertension ES and Cardiology ES. 2013 ESH/ESC Guidelines for the management of arterial hypertension. Blood Pressure 22: 193-278.

6. Raised blood pressure: Situation and trends. World Health Organization. 2014.

7. Heidenreich PA, Trogdon JG, Khavjou OA, Butler J, Dracup K, et al. (2011). Forecasting the Future of Cardiovascular Disease in the United States A Policy Statement From the American Heart Association. Circulation 123: 933-944.

8. Law MR, Morris JK, Wald NJ (2009) Use of blood pressure lowering drugs in the prevention of cardiovascular disease: meta-analysis of 147 randomised trials in the context of expectations from prospective epidemiological studies. See comment in PubMed Commons below BMJ 338: b1665.

9. Hales S. Statistical essays, containing haemastaticks. London: W Innys, R Manby, and T. Woodward; 1733.

10. Booth J (1977) A short history of blood pressure measurement. See comment in PubMed Commons below Proc R Soc Med 70: 793-799.

11. Smirk FH (1944) Casual and Basal Blood Pressures Iv. Their Relationship to the Supplemental Pressure with a Note on Statistical Implications. British heart journal 6: 176-182. 
12. Fisher JW (1914) The diagnostic value of the sphygmomanometer in examinations for life insurance. J Amer Med Assoc 63:1752-1754.

13. Kylin E (1923) Studien: hypertonie-hyperglykamiehyperurikamiesyndrome. Zentralblatt fur InnereMedizin44.

14. VAGUE J (1947) [Not Available]. See comment in PubMed Commons below Presse Med 55: 339.

15. Weber MA, Schiffrin EL, White WB, Mann S, Lindholm LH, et al. (2014) Clinical Practice Guidelines for the Management of Hypertension in the Community A Statement by the American Society of Hypertension and the International Society of Hypertension. J ClinHypertens 16: 14-26.

16. Weber MA, Schiffrin EL, White WB, Mann S, Lindholm LH, et al. (2014) Clinical Practice Guidelines for the Management of Hypertension in the Community A Statement by the American Society of Hypertension and the International Society of Hypertension. J Hypertens 32: 3-15.

17. Carretero OA, Oparil S (2000) Essential hypertension : part II: treatment. See comment in PubMed Commons below Circulation 101: 446-453.

18. Beevers G, Lip GY, O'Brien E (2001) ABC of hypertension: The pathophysiology of hypertension. See comment in PubMed Commons below BMJ 322: 912-916.

19. Mayet J, Hughes A (2003) Cardiac and vascular pathophysiology in hypertension. See comment in PubMed Commons below Heart 89: 1104-1109.

20. Mark AL (1996) The sympathetic nervous system in hypertension: a potential long-term regulator of arterial pressure. See comment in PubMed Commons below J HypertensSuppl 14: S159-165.

21. Kim JR, Kiefe CI, Liu K, Williams OD, Jacobs DR Jr, et al. (1999) Heart rate and subsequent blood pressure in young adults: the CARDIA study. See comment in PubMed Commons below Hypertension 33: 640-646.

22. Cain AE, Khalil RA (2002) Pathophysiology of essential hypertension: role of the pump, the vessel, and the kidney. See comment in PubMed Commons below SeminNephrol 22: 3-16.

23. Cody RJ (1997) The sympathetic nervous system and the reninangiotensin-aldosterone system in cardiovascular disease. See comment in PubMed Commons below Am J Cardiol 80: 9J-14J.

24. Sarzani R, Salvi F, Dessì-Fulgheri P, Rappelli A (2008) Renin-angiotensin system, natriuretic peptides, obesity, metabolic syndrome, and hypertension: an integrated view in humans. See comment in PubMed Commons below J Hypertens 26: 831-843.

25. Ferrario CM (2006) Role of angiotensin II in cardiovascular disease therapeutic implications of more than a century of research. See comment in PubMed Commons below J Renin Angiotensin Aldosterone Syst 7: 3-14.

26. Piepho RW, Beal J (2000) An overview of antihypertensive therapy in the 20th century. See comment in PubMed Commons below J ClinPharmacol 40: 967-977.

27. Simões E Silva AC, Flynn JT (2012) The renin-angiotensin-aldosterone system in 2011: role in hypertension and chronic kidney disease. See comment in PubMed Commons below PediatrNephrol 27: 1835-1845.

28. Atlas SA (2007) The renin-angiotensin aldosterone system: pathophysiological role and pharmacologic inhibition. See comment in PubMed Commons below J Manag Care Pharm 13: 9-20.

29. Mulatero P, Verhovez A, Morello F, Veglio F (2007) Diagnosis and treatment of low-renin hypertension. See comment in PubMed Commons below ClinEndocrinol (Oxf) 67: 324-334.

30. Kobori H, Nangaku M, Navar LG, Nishiyama A (2007) Theintrarenal renin-angiotensin system: from physiology to the pathobiology of hypertension and kidney disease. See comment in PubMed Commons below Pharmacol Rev 59: 251-287.

31. Mitchell KD, Botros FT, Navar LG (2007) Intrarenal renin-angiotensin system and counteracting protective mechanisms in angiotensin IIdependent hypertension. See comment in PubMed Commons below ActaPhysiol Hung 94: 31-48.

32. Admiraal PJ, Danser AH, Jong MS, Pieterman H, Derkx FH, et al. (1993) Regional angiotensin II production in essential hypertension and renal artery stenosis. See comment in PubMed Commons below Hypertension 21: 173-184.

33. Cardillo C, Kilcoyne CM, Quyyumi AA, Cannon RO, 3rd and Panza J (1998). Selective defect in nitric oxide synthesis may explain the impaired endothelium-dependent vasodilation in patients with essential hypertension. Circulation 97: 851-856.

34. Panza JA, Casino PR, Kilcoyne CM and Quyyumi AA (1993). Role of endothelium-derived nitric oxide in the abnormal endotheliumdependent vascular relaxation of patients with essential hypertension. Circulation 87: 1468-1474.

35. Panza JA, Garcia CE, Kilcoyne CM, Quyyumi AA and Cannon RO (1995) 3rd. Impaired endothelium-dependent vasodilation in patients with essential hypertension. Evidence that nitric oxide abnormality is not localized to a single signal transduction pathway. Circulation 91: 1732-1738.

36. Panza JA, Quyyumi AA, Brush JE Jr, Epstein SE (1990) Abnormal endothelium-dependent vascular relaxation in patients with essential hypertension. See comment in PubMed Commons below N Engl J Med 323: 22-27.

37. Benjamin EJ, Larson MG, Keyes MJ, Mitchell GF, Vasan RS, et al. (2004) Clinical correlates and heritability of flow-mediated dilation in the community: the Framingham Heart Study. See comment in PubMed Commons below Circulation 109: 613-619.

38. Sander M, Chavoshan B, Victor RG (1999) A large blood pressure-raising effect of nitric oxide synthase inhibition in humans. See comment in PubMed Commons below Hypertension 33: 937-942.

39. Shimbo D, Muntner P, Mann D, Viera AJ, Homma S, et al. (2010) Endothelial dysfunction and the risk of hypertension: the multi-ethnic study of atherosclerosis. See comment in PubMed Commons below Hypertension 55: 1210-1216.

40. Juonala M, Viikari JS, Rönnemaa T, Helenius H, Taittonen L, et al. (2006) Elevated blood pressure in adolescent boys predicts endothelial dysfunction: the cardiovascular risk in young Finns study. See comment in PubMed Commons below Hypertension 48: 424-430.

41. Coca-Robinot D, Fabregate R, Sanchez-Largo E, Fernandez E, Marquez J, et al. (2005) Clinical, biochemical and cardiovascular implications of endothelial dysfunction in the dermal microcirculation. American journal of hypertension 18: 177A-178A.

42. Widlansky ME, Gokce N, Keaney JF Jr, Vita JA (2003) The clinical implications of endothelial dysfunction. See comment in PubMed Commons below J Am CollCardiol 42: 1149-1160.

43. Hill JM, Zalos G, Halcox JP, Schenke WH, Waclawiw MA, et al. (2003) Circulating endothelial progenitor cells, vascular function, and cardiovascular risk. See comment in PubMed Commons below N Engl J Med 348: 593-600.

44. Urbich C, Dimmeler S (2004) Endothelial progenitor cells: characterization and role in vascular biology. See comment in PubMed Commons below Circ Res 95: 343-353.

45. Deanfield J, Donald A, Ferri C, Giannattasio C, Halcox J, et al. (2005) Endothelial function and dysfunction. Part I: Methodological issues for assessment in the different vascular beds: A statement by the Working Group on Endothelin and Endothelial Factors of the European Society of Hypertension. J Hypertens 23:7-17.

46. Hickey KA, Rubanyi G, Paul RJ, Highsmith RF (1985) Characterization of a coronary vasoconstrictor produced by cultured endothelial cells. See comment in PubMed Commons below Am J Physiol 248: C550-556.

47. Wagner OF, Christ G, Wojta J, Vierhapper H, Parzer S, et al. (1992) Polar secretion of endothelin-1 by cultured endothelial cells. See comment in PubMed Commons below J BiolChem 267: 16066-16068.

48. Vierhapper H, Wagner O, Nowotny P, Waldhäusl W (1990) Effect of endothelin-1 in man. See comment in PubMed Commons below Circulation 81: 1415-1418.

49. Krum H, Viskoper RJ, Lacourciere Y, Budde M and Charlon V (1998) The effect of an endothelin-receptor antagonist, bosentan, on blood pressure in patients with essential hypertension. Bosentan Hypertension Investigators. The New England journal of medicine 338: 784-790. 
50. Levin ER (1995) Endothelins. See comment in PubMed Commons below N Engl J Med 333: 356-363.

51. Mattson DL, Cowley AW Jr (1993) Kinin actions on renal papillary blood flow and sodium excretion. See comment in PubMed Commons below Hypertension 21: 961-965.

52. McGiff JC, Itskovitz HD, Terragno NA (1975) The actions of bradykinin and eledoisin in the canine isolated kidney: relationships to prostaglandins. See comment in PubMed Commons below ClinSciMol Med 49: 125-131.

53. Pasquié JL, Herizi A, Jover B, Mimran A (1999) Chronic bradykinin infusion and receptor blockade in angiotensin II hypertension in rats. See comment in PubMed Commons below Hypertension 33: 830-834.

54. Dendorfer A, Wolfrum S, Dominiak P (1999) Pharmacology and cardiovascular implications of the kinin-kallikrein system. See comment in PubMed Commons below Jpn J Pharmacol 79: 403-426.

55. Linz W, Wiemer G, Gohlke P, Unger T, Schölkens BA (1995) Contribution of kinins to the cardiovascular actions of angiotensinconverting enzyme inhibitors. See comment in PubMed Commons below Pharmacol Rev 47: 25-49.

56. Brenner BM, Ballermann BJ, Gunning ME, Zeidel ML (1990) Diverse biological actions of atrial natriuretic peptide. See comment in PubMed Commons below Physiol Rev 70: 665-699.

57. Garcia R, Thibault G, Gutkowska J, Cantin M, Genest J (1985) Changes of regional blood flow induced by atrial natriuretic factor (ANF) in conscious rats. See comment in PubMed Commons below Life Sci 36: 1687-1692.

58. Hypertension (2011) The Clinical Management of Primary Hypertension in Adults: Update of Clinical Guidelines 18 and 34 London.

59. Mancia G, Fagard R, Narkiewicz K, Redon J, Zanchetti A, et al. (2013) ESH/ESC Practice Guidelines for the Management of Arterial Hypertension. Blood Press. 23: 3-16.

60. Peralta CA, Norris KC, Li S, Chang TI, Tamura MK, et al. (2012) Blood pressure components and end-stage renal disease in persons with chronic kidney disease: the Kidney Early Evaluation Program (KEEP). Archives of internal medicine 172:41-47.

61. Wright JT, Jr., Bakris G, Greene T, Agodoa LY, Appel LJ, et al. (2002) Effect of blood pressure lowering and antihypertensive drug class on progression of hypertensive kidney disease: results from the AASK trial. JAMA : the journal of the American Medical Association 288:2421-2431.

62. Lewington S, Clarke R, Qizilbash N, Peto R, Collins R, et al. (2002) Agespecific relevance of usual blood pressure to vascular mortality: a metaanalysis of individual data for one million adults in 61 prospective studies. Lancet 360: 1903-1913.

63. Elmer PJ, Obarzanek E, Vollmer WM, Simons-Morton D, Stevens VJ, et al. (2006) Effects of comprehensive lifestyle modification on diet, weight, physical fitness, and blood pressure control: 18-month results of a randomized trial. Annals of internal medicine 144: 485-95.

64. Officers A (2002) Coordinators for the ACRGTA and Lipid-Lowering Treatment to Prevent Heart Attack T. Major outcomes in high-risk hypertensive patients randomized to angiotensin-converting enzyme inhibitor or calcium channel blocker vs diuretic: The Antihypertensive and Lipid-Lowering Treatment to Prevent Heart Attack Trial (ALLHAT). JAMA : the journal of the American Medical Association 288:2981-2997.

65. Hollenberg NK (2003). The Antihypertensive and Lipid-Lowering Treatment to Prevent Heart Attack Trial (ALLHAT). Major outcomes in high-risk hypertensive patients randomized to angiotensin-converting enzyme inhibitor or calcium channel blocker vs diuretic. Curr Hypertens Rep 5: 183-185.

66. Pahor M, Psaty BM, Alderman MH, Applegate WB, Williamson JD, et al. (2000) Therapeutic benefits of ACE inhibitors and other antihypertensive drugs in patients with type 2 diabetes. Diabetes care 23: 888-892.

67. Parving $\mathrm{HH}$ and Rossing P (2001). Therapeutic benefits of ACE inhibitors and other antihypertensive drugs in patients with type 2 diabetes. Diabetes care. 2001;24:177-180.

68. Flather MD, Yusuf S, Kober L, Pfeffer M, Hall A, et al. (2000) Long-term ACE-inhibitor therapy in patients with heart failure or left-ventricular dysfunction: a systematic overview of data from individual patients. ACE-Inhibitor Myocardial Infarction Collaborative Group. Lancet 355: 1575-1581.

69. Brophy JM and Joseph L (2000) Long-term ACE-inhibitor therapy. Lancet 356:338.

70. Dahlof B, Devereux R, de Faire U, Fyhrquist F, Hedner T, et al. (1997). The Losartan Intervention For Endpoint reduction (LIFE) in Hypertension study: rationale, design, and methods. The LIFE Study Group. American journal of hypertension 10: 705-713.

71. Costanzo P, Perrone-Filardi P, Petretta M, Marciano C, Vassallo E, et al (2009) Calcium channel blockers and cardiovascular outcomes: a metaanalysis of 175,634 patients. J Hypertens 27:1136-1151.

72. Psaty BN, Lumley T, Furberg CD, Schellenbaum G, Pahor M, et al.(2003) Health outcomes associated with various antihypertensive therapies used as first-line agents - A network meta-analysis. Jama-J Am Med Assoc 289:2534-2544.

73. Wing LM, Reid CM, Ryan P, Beilin LJ, Brown MA, et al. (2003). Second Australian National Blood Pressure Study G. A comparison of outcomes with angiotensin-converting--enzyme inhibitors and diuretics for hypertension in the elderly. The New England journal of medicine 348: 583-592.

74. Pitt B, Zannad F, Remme WJ, Cody R, Castaigne A, et al. (1999) The effect of spironolactone on morbidity and mortality in patients with severe heart failure. Randomized Aldactone Evaluation Study Investigators. The New England journal of medicine 341: 709-717.

75. Gress TW, Nieto FJ, Shahar E, Wofford MR, Brancati FL(2000). Hypertension and antihypertensive therapy as risk factors for type 2 diabetes mellitus. Atherosclerosis Risk in Communities Study. The New England journal of medicine 342:905-912.

76. Hulley SB, Furberg CD, Gurland B, McDonald R, Perry HM, et al. (1985) Systolic Hypertension in the Elderly Program (SHEP): antihypertensive efficacy of chlorthalidone. The American journal of cardiology 56: 913-920.

77. Shafi T, Appel LJ, Miller ER, 3rd, Klag MJ and Parekh RS, et al. (2008). Changes in serum potassium mediate thiazide-induced diabetes. Hypertension 52:1022-1029.

78. Ezekowitz JA and McAlister FA(2009) Aldosterone blockade and left ventricular dysfunction: a systematic review of randomized clinical trials. Eur Heart J. 30: 469-477.

79. Pitt B, Remme W, Zannad F, Neaton J, Martinez F, et al. (2003). Eplerenone Post-Acute Myocardial Infarction Heart Failure E and Survival Study I. Eplerenone, a selective aldosterone blocker, in patients with left ventricular dysfunction after myocardial infarction. The New England journal of medicine 348:1309-1321.

80. Cuculi F, Suter A and Erne P (2007) Spironolactone-induced gynecomastia. CMAJ : Canadian Medical Association journal journal de l'Association medicale canadienne 176: 620.

81. Kiernan MS and Konstam MA (2012) Moderate renal insufficiency does not attenuate the clinical benefit of aldosterone antagonists in heart failure. J Am Coll Cardiol 60: 2090-2091.

82. Rose LI, Underwood RH, Newmark SR, Kisch ES and Williams GH (1977) Pathophysiology of spironolactone-induced gynecomastia. Annals of internal medicine 87: 398-403.

83. Svensson M, Gustafsson F, Galatius S, Hildebrandt PR and Atar D (2003) Hyperkalaemia and impaired renal function in patients taking spironolactone for congestive heart failure: retrospective study. Bmj 327: 1141-1142.

84. Vardeny O, Wu DH, Desai A, Rossignol P, Zannad F, et al. (2012) Influence of baseline and worsening renal function on efficacy of spironolactone in patients With severe heart failure: insights from RALES (Randomized Aldactone Evaluation Study). J Am Coll Cardiol 60: 2082-2089.

85. Sanoski CA (2009) Aliskiren: an oral direct renin inhibitor for the treatment of hypertension. Pharmacotherapy 29: 193-212.

86. Gheorghiade M (2013) Effect of Aliskiren on Postdischarge Mortality and Heart Failure Readmissions Among Patients Hospitalized for Heart 
Citation: Delacroix S, Chokka RC, Worthley SG (2014) Hypertension: Pathophysiology and Treatment. J Neurol Neurophysiol 5: 250. doi: 10.4172/2155-9562.1000250

Page 8 of 8

Failure: The ASTRONAUT Randomized Trial (vol 309, pg 1125, 2013). Jama-J Am Med Assoc 309: 1461-1461.

87. Parving HH, Brenner BM, McMurray JJ, de Zeeuw D, Haffner SM, et al. (2012) Cardiorenal end points in a trial of aliskiren for type 2 diabetes. The New England journal of medicine 367:2204-2213.

88. Parving HH, Brenner BM, McMurray JJV, de Zeeuw D, Haffner SM, et al. (2009) Aliskiren Trial in Type 2 Diabetes Using Cardio-Renal Endpoints (ALTITUDE): rationale and study design. Nephrol Dial Transpl 24: 1663-1671.

89. Sureshkumar KK (2008) Renin inhibition with aliskiren in hypertension: focus on aliskiren/hydrochlorothiazide combination therapy. Vascular health and risk management 4: 1205-1220.

90. Worthley MI, Corti R and Worthley SG (2004) Vasopeptidase inhibitors: will they have a role in clinical practice? British journal of clinical pharmacology 57: 27-36.

91. Calhoun DA, Jones D, Textor S, Goff DC, Murphy TP, et al. (2008) Resistant hypertension: diagnosis, evaluation, and treatment: a scientific statement from the American Heart Association Professional Education Committee of the Council for High Blood Pressure Research. Circulation 117: e510-e526.

92. Daugherty SL, Powers JD, Magid DJ, Tavel HM, Masoudi FA, et al. (2012) Incidence and prognosis of resistant hypertension in hypertensive patients. Circulation 125: 1635-1642.
93. Freis E (1995) Hypertension: Pathophysiology,Diagnosis and Management. 2 ed. New York: Raven

94. Krum H, Schlaich M, Whitbourn R, Sobotka PA, Sadowski J, et al. (2009) Catheter-based renal sympathetic denervation for resistant hypertension: a multicentre safety and proof-of-principle cohort study. Lancet 373 : 1275-1281.

95. Esler MD, Krum H, Sobotka PA, Schlaich MP, Schmieder RE, et al (2010) Renal sympathetic denervation in patients with treatmentresistant hypertension (The Symplicity HTN-2 Trial): a randomised controlled trial. Lancet 376: 1903-1909.

96. Symplicity HTNI (2011) Catheter-based renal sympathetic denervation for resistant hypertension: durability of blood pressure reduction out to 24 months. Hypertension 57: 911-917.

97. Worthley SG, Tsioufis CP, Worthley MI, Sinhal A, Chew DP, et al. (2013) Safety and efficacy of amulti-electrode renal sympathetic denervation systemin resistant hypertension: the EnligHTN I trial. Eur Heart J. 34: 2132-2140.

98. Chokka RG, Delacroix S, Psaltis PJ, Anavekar NS and Worthley SG (2014) Percutaneous renal denervation and the second generation EnligHTN System. Minerva cardioangiologica 62: 99-104. 